\title{
T-cell co-stimulatory molecules: their role in allergic immune reactions
}

\author{
T. Kallinich, K.C. Beier, U. Wahn, P. Stock and E. Hamelmann
}

ABSTRACT: The development of allergic diseases, such as allergic asthma, depends upon the initiation and maintenance of T-helper cell type-2-skewed allergen-specific immune reactions. Although it is clear that susceptibility to this process is under genetic and environmental control, the fine-tuning and regulation of the type-2 T-helper cell immune response is not yet fully understood. In this second article in the present series, current understanding regarding the involvement of T-cells and antigen-presenting cells is summarised, with emphasis on the interaction between these two types of immune regulatory cells by means of co-stimulatory molecules.

\section{KEYWORDS: Allergic airway inflammation, asthma pathogenesis, co-stimulation, T-cells}

\section{SPECIFIC CD4+ T-CELL SUBSETS CONTRIBUTE TO ALLERGIC AIRWAY DISEASE DEVELOPMENT}

CD4+ T-cells play a central role in the initiation and maintenance of the allergic airway reaction. By expression of major histocompatibility complex (MHC) class II molecules and allergenspecific T-cell receptors (TCRs) they link innate and adoptive immune responses. They induce the synthesis of allergen-specific immunoglobulin $(\mathrm{Ig}) \mathrm{E}$ and recruit and activate effector cells, such as eosinophils, via the secretion of soluble factors. Their pivotal role in controlling the early and late asthmatic reaction was convincingly demonstrated in human patients, as well as in animal models of allergic airway inflammation. Activated T-cells were found in increased numbers in the bronchial tissues of asthmatic subjects $[1,2]$, and depletion of CD4+ T-cells in a mouse model of allergic airway disease impressively prevented both the development of airway hyperresponsiveness (AHR) and the infiltration of eosinophils into the airways [3].

T-cells were originally subdivided, according to their functional properties, into two polarised subsets [4]. Type- 1 T-helper cells (Th) predominantly produce the cytokines tumour necrosis factor (TNF)- $\beta$, interferon- $\gamma$ and interleukin (IL)-2 and stimulate a strong cell-mediated immune response, particularly against intracellular pathogens. In contrast, Th2 have the capacity to secret greater amounts of IL-4, -5, -9 and IL-13, and are therefore crucial for allergic immune reactions.

The first report on the specific cytokine profile of T-cells involved in the pathogenesis of human asthma was published in the early 1990s, demonstrating that T-cells in bronchoalveolar lavage fluid (BALF) from asthmatic patients predominantly produce the Th2-type cytokines granulocyte-macrophage colony-stimulating factor and IL-3, -4 and $-5[5,6]$. The functional importance of these cells for the development of allergic airway inflammation was further persuasively demonstrated by analyses in rodents. Mice lacking pivotal elements required for the induction of Th2 immune reactions, e.g. signal transducer and activator of transcription $6[7,8]$, failed to develop symptoms of allergic airway inflammation. Similarly, athymic mice with no functional peripheral T-cells also lack eosinophilic airway infiltration and increased AHR following allergen sensitisation, unless production of the Th2 cytokine IL- 5 is restored by systemic administration [9]. Although the involvement of Th2 cytokines explains the biological basis of many features of the allergic reaction (e.g. recruitment

Previous articles in this series: No. 1: Beier KC, Kallinich T, Hamelmann E. Master switches of T-cell activation and differentiation. Eur Respir $J$

\section{AFFILIATIONS}

Dept of Paediatrics, Division of Pneumology and Immunology, Charité Medical University of Berlin, Berlin, Germany.

\section{CORRESPONDENCE}

E. Hamelmann

Dept of Paediatrics

Division of Pneumology and

Immunology

Charité Medical University of Berlin

Campus Virchow-Klinikum

Augustenburger Platz 1

13353 Berlin

Germany

Fax: 4930450566931

E-mail: eckard.hamelmann@

charite.de

Received:

July 182006

Accepted after revision:

January 062007

STATEMENT OF INTEREST

None declared. 
of eosinophils, activation of mast cells, airway remodelling and IgE production), it has been observed more recently that asthmatic individuals may also exhibit an increased Th1-like response to allergens $[10,11]$, especially in established disease [12-15]. Conversely, acute segmental allergen challenges lead to a reduction in Th1 cytokine-producing T-cell numbers [16]. In summary, the dogma of the allergic reaction being purely a Th2-driven disease, especially as an attempt to explain asthma pathology, is questioned; however, the important role of Th2 cytokines, such as IL- $4,-5$ and -13 , has been demonstrated by a large body of evidence.

The important role of the various Th2 cytokines in the development of allergic airway inflammation was further demonstrated by analysis of the pathology of mice overexpressing certain Th2 cytokines, by use of cytokine-blocking agents or genetically deficient mice unable to produce specific cytokines (table 1). In conclusion, these data clearly underline the importance of the Th2 subset in the pathogenesis of allergic (airway) diseases.

Encouraged by these experimental in vitro and in vivo data, trials were performed with the aim of therapeutically targeting Th2 cytokines in human subjects with persistent asthma (Global Initiative for Asthma stage 2 or worse). Single intravenous application of a humanised monoclonal antibody $(\mathrm{mAb})$ directed against IL-5 (SB-240563/mepolizumab) in patients with mild persistent asthma significantly reduced the numbers of eosinophils in the peripheral blood and sputum, but had no significant effect on the late asthmatic response, or on nonspecific AHR to histamine [37]. Later, in patients with mild/moderate asthma undergoing a prolonged protocol of repeated antibody treatment, it was shown that, although eosinophils were nearly wiped out in the periphery, signs of eosinophil activation and degranulation were still present in the lung tissues, probably accounting for the lack of efficacy [38]. In another trial, in patients with severe persistent asthma, with a different humanised $\mathrm{mAb}$ directed against IL-5, SCH55700, numbers of circulating eosinophils were also reduced, but, besides a small increase in baseline forced expiratory volume in one second (FEV1), there was no effect on other clinical indices of disease activity [39]. In mild-tomoderate asthmatic subjects, application of a recombinant soluble IL-4 receptor by inhalation during dose-reduction and withdrawal of inhaled corticosteroids prevented a decline in FEV1 or an increase in asthma symptoms $[40,41]$. Since there

\begin{tabular}{|lccc}
\hline TABLE 1 & $\begin{array}{c}\text { Involvement of type-2 T-helper cell cytokines in the } \\
\text { pathogenesis of allergic airway inflammation } \\
\text { (selected mouse studies) }\end{array}$ \\
\hline & $\begin{array}{c}\text { Cytokine-blocking } \\
\text { agent }\end{array}$ & $\begin{array}{c}\text { Cytokine } \\
\text { overexpression }\end{array}$ & $\begin{array}{c}\text { Cytokine } \\
\text { deficiency }\end{array}$ \\
\hline IL-4 & {$[17,18]$} & & {$[19,20]$} \\
IL-5 & {$[21,22]$} & {$[23-25]$} & {$[20,26,27]$} \\
IL-9 & {$[28]$} & {$[31]$} \\
IL-13 & {$[32-34]$} & {$[35]$} & {$[36]$} \\
\hline IL: interleukin. & \multicolumn{3}{c}{} \\
\hline
\end{tabular}

was a lack of further evidence of efficacy, this strategy has since been discontinued, as have those with an anti-IL-5 approach.

These rather frustrating outcomes of trials in which the blockade of a single Th2 cytokine was attempted may be explained in various ways: 1 ) the applied compounds did not sufficiently deplete and antagonise eosinophils and IL-4, respectively; 2) eosinophils might not be totally required or even important in the clinical manifestation of asthma [42]; 3) other trigger factors, such as viral infections, exercise or airway pollution, might account for asthma pathology and/or exacerbation; and 4) depletion of a single cytokine is not sufficient, due to the high redundancy of effector function of a wide variety of cytokines [38]. It is, therefore, tempting to speculate that elimination of the entire Th2 function or the complete prevention of differentiation towards the Th2 type may overcome the problem of redundant cytokine function (discussed in the next article in the present series [43]). Also, different treatment protocols, including early and/or prolonged intervention and the use of antibody cocktails aimed at a variety of cytokines, might result in increased efficacy in asthma therapy.

Furthermore, there are new data showing that strategies targeting T-cells and/or T-cell products that are not linked with a Th1/Th2 bias may be effective in the treatment of asthma. Selective blockade of TNF- $\alpha$ using the TNF receptor- 2 Fc fusion protein etanercept, as well as the application of methotrexate, to suppress TNF- $\alpha$ as well as antibody production, led to a reduction in asthma severity [44, 45]. In summary, these data are in line with a concept of impaired immunostasis being the main reason for asthma development, with unwanted immune reactions of allergen-specific CD4+ T-cells due to the lack of regulatory $\mathrm{T}$-cell $(\mathrm{Tr})$ functions inducing the allergic cascade, regardless of Th1 or Th2 bias [46].

\section{ALLERGIC AIRWAY INFLAMMATION REGULATION BY SPECIFIC T-CELLS}

The term regulatory $\mathrm{T}$-cell $(\mathrm{Tr})$ refers to cells that actively control or suppress the function of other cells, generally in an inhibitory fashion. Tr appear to control the development of autoimmune disease and transplant rejection, and may also play a critical role in controlling the expression of asthma and allergy. Their specific characterisation, as well as their mode of action, is still undergoing intense investigation [47]. However, different $\mathrm{Tr}$ subtypes with certain attributes and functions may be described.

Naturally occurring Tr are positively selected in the thymus by encountering self antigen. They constitute $5-10 \%$ of CD4+ Tcells in the periphery in both mice and humans. These cells constitutively express CD25 (IL-2 receptor), as well as the transcription factor forkhead box protein (Fox) P3 [48-50], which acts as a specific factor for the differentiation of the $\mathrm{Tr}$ lineage and closely correlates with the suppressor activity of the cells [51].

The precise function of FoxP3, which until recently was thought to be expressed only by natural CD25+ Tr, is not known, but absence of FoxP3 in humans results in immunodysregulation, polyendocrinopathy, enteropathy, X-linked (IPEX) syndrome $[52,53]$, also know as $X$-linked autoimmunity-allergic 
dysregulation syndrome [54]. Patients with IPEX syndrome share many phenotypic features with scurfy mice, which have a natural mutation in the gene encoding FoxP3, and lack natural CD25+ Tr. Scurfy mice develop diarrhoea, malabsorption, autoimmune haemolytic anaemia, thrombocytopenia, leukocytosis, lymphadenopathy, hepatosplenomegaly, hypogonadism and dry skin, which are all corrected by adoptive transfer of natural CD25+ Tr into these mice [55]. In addition, forced expression of the FoxP3 gene, which encodes a transcription repressor, converts naive murine T-cells into Tr that phenotypically and functionally resemble natural CD25+ Tr.

Although the absence of FOXP3 expression in patients with IPEX syndrome and scurfy mice eliminates development of natural CD25+ Tr, whether IPEX syndrome patients and scurfy mice also lack adaptive $\operatorname{Tr}$ that differentiate in the periphery from CD25- T-cells is not yet clear. However, since patients with IPEX syndrome develop eczema, food allergy, elevated $\operatorname{IgE}$ levels and peripheral eosinophilia, associated with elevated Th2 cytokine production [54], the present authors suggest that IPEX syndrome patients lack both natural CD25+ $\mathrm{Tr}$ and antigen-specific adaptive $\mathrm{Tr}$, which may be particularly effective in regulating Th2 responses to allergens.

In mice, natural CD25+ Tr have been shown to limit allergeninduced airway inflammation but not the development of airway hyperreactivity [56]. In these experimental settings, pre-activation of natural $\mathrm{Tr}$ by nonspecific signals appears to be required in order to obtain strong inhibition of allergeninduced airway inflammation [57].

In children who have outgrown cow's milk sensitivity, an increased frequency of circulating natural $\mathrm{Tr}$ is associated with decreased in vitro proliferative responses to the specific allergen bovine $\beta$-lactoglobulin [58]. Natural CD25+ Tr from nonallergic, but not from allergic, donors suppress proliferation and IL-5 secretion by allergen-stimulated CD4+CD25effector T-cells, indicating that natural Tr may also suppress allergic immune responses to inhaled allergens, e.g. cat allergen or grass-pollen [59]. Interestingly, in allergic donors, the inhibitory activity of CD25+ Tr on the production of Th2 cytokines was most suppressed when pollen counts were highest during the specific season. Accordingly, natural $\mathrm{Tr}$ from both allergic and nonallergic individuals suppressed $\mathrm{T}$ cell proliferation and Th2 cytokine production in response to birch allergen most potently outside, but not during the birch pollen season [60].

Although it is clear that natural Tr are positively selected in the thymus after encounter with self antigens, it is likely that allergen-specific adaptive $\operatorname{Tr}$ develop in the periphery after encounters with exogenous allergens (e.g. from food or plants). Adaptive Tr do not have clearly defined markers that would make them easily identified or isolated; thus their further characterisation is difficult to accomplish.

Several studies have analysed the significance of co-stimulatory pathways in the generation and expansion of Tr. First, it was demonstrated that rat Tr respond less well than CD25- Tcells to conventional co-stimulation, but are readily expanded in vitro by superagonistic CD28-specific mAbs, which are potent mitogens for all T-cells without the need for TCR engagement [61]. In vivo, functional $\mathrm{Tr}$ are preferentially expanded over other T-cell subsets by CD28 stimulation. These data suggest that CD28-driven activation of Tr may be effective in the treatment of inflammatory and autoimmune diseases, but side-effects should be carefully taken into account [62].

In addition, co-stimulation of CD4+ T-cells with anti-CD52 $\mathrm{mAb}$ leads to the development of $\operatorname{Tr}$ that suppress the polyclonal responses of CD4+ T-cells [63]. These Tr had the potential to suppress graft-versus-host disease-like pathology in severe combined immunodeficiency syndrome mice injected with human peripheral blood mononuclear cells. It was suggested that anti-CD52-induced Tr, which can be expanded and which confer antigen specificity, have the potential to be a desirable tool in cellular immunotherapy.

\section{T-CELLS SHOW SPECIFIC DIFFERENTIATION AND MIGRATION IN ALLERGIC AIRWAY INFLAMMATION}

The differentiation of T-cell function depends upon the recognition of a specific peptide presented by antigenpresenting cells (APCs) in combination with additional costimulatory signals, as described in the first article in the present series [64]. In recent years, a variety of studies have broadened knowledge of the cellular interaction leading to Tcell differentiation in allergic airway inflammation.

The allergic immune response is initiated by pulmonary dendritic cells (DCs), derived from blood monocytes with low granulocyte-differentiation antigen $(\mathrm{Gr})-1$ and high $\mathrm{CX}_{3} \mathrm{C}$ chemokine receptor 1 densities [65]. They are located underneath the basal membrane of the airway epithelium, where they encounter and incorporate allergens and migrate to the draining thoracic lymph nodes (fig. 1) [66]. As soon as the DCs carrying the allergen peptides arrive in the T-cell area of the local lymph node, they stimulate specific naive or memory $\mathrm{T}$ cells by increasing expression of co-stimulatory and MHC class II molecules. Under conditions in which allergen exposure is accompanied by an inflammatory stimulus, differentiation towards functional effector T-cells, $\mathrm{Tr}$ or memory T-cells is induced [67]. Activated effector T-cells leave the lymph node and enter the pulmonary tissues, the site of further antigen deposition, where they are retained in a nonproliferative state, recognising antigens presented by local DCs [68]. They further enhance the recruitment and maturation of other immune cells involved in the allergic cascade, such as eosinophils and mast cells, via the secretion of cytokines and chemokines.

\section{IMPACT OF INNATE IMMUNITY ON T-CELL DIFFERENTIATION AND DEVELOPMENT OF THE ASTHMA PHENOTYPE}

The innate immune system links environmental factors with the specific responses of adaptive immunity. A family of evolutionarily highly conserved receptors, known as Toll-like receptors (TLRs), are expressed by APCs and recognise pathogen-associated molecular patterns. This interaction leads to secretion of different cytokines by the APCs, including IL-12, particularly promoting the development of Th1 [69]. The epidemiological observation that the modified exposure to microbial particles in westernised areas is associated with a reduced prevalence of atopic diseases, the so-called "hygiene hypothesis", may thus be explained by the reduced production of IL-12 shifting the immune responses to a predominantly Th2 


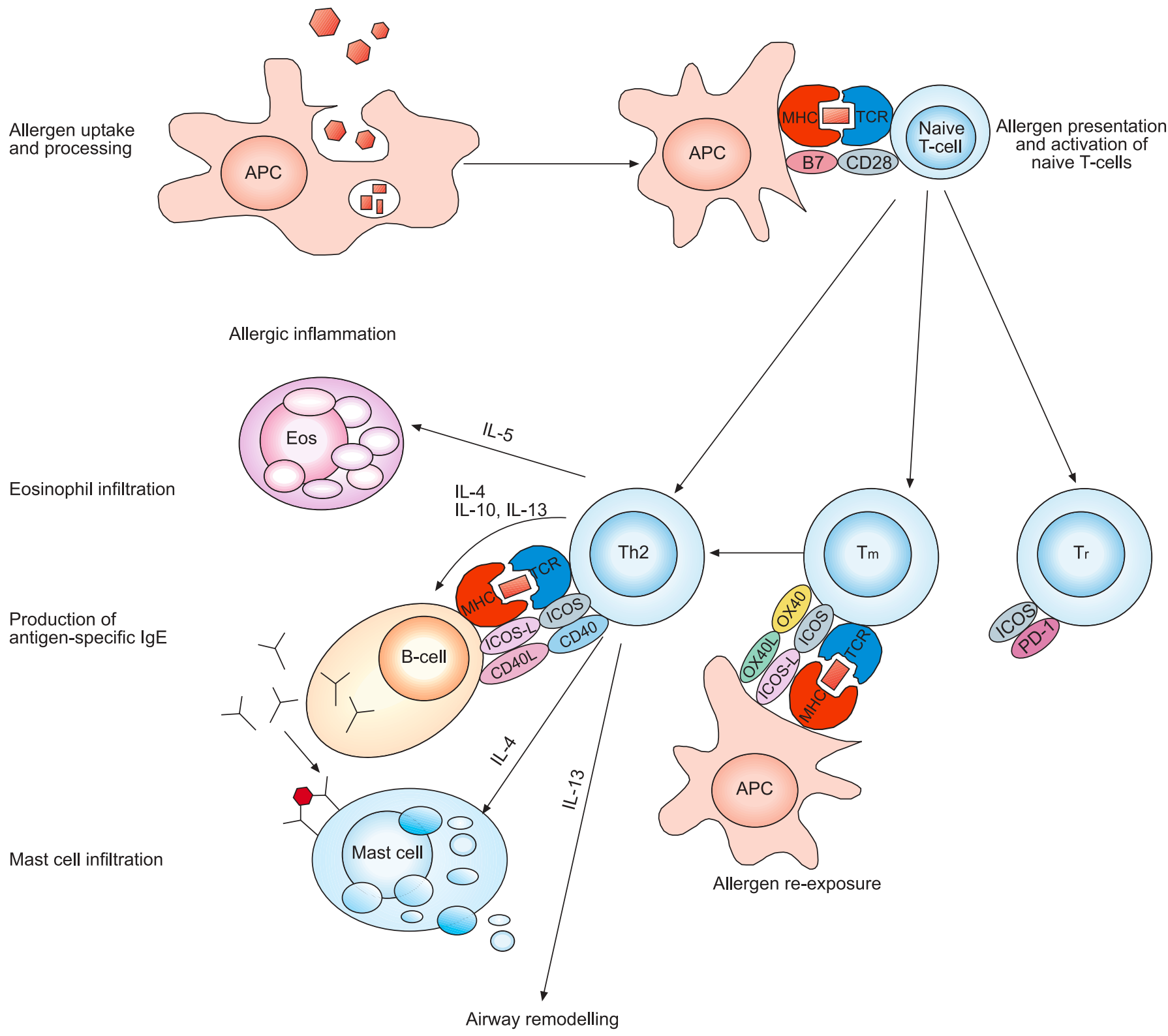

FIGURE 1. Cellular and molecular events in the development of allergic reaction. APC: antigen-presenting cell; MHC: major histocompatibility complex; TCR: T-cell receptor; IL: interleukin; Eos: eosinophil; Ig: immunoglobulin; Th: T-helper cell; ICOS: inducible co-stimulatory antigen; ICOS-L: ICOS ligand; CD40L: CD40 ligand; Tm: memory T-cell; OX40: CD134; OX40L: OX40 ligand; Tr: regulatory T-cell; PD: programmed cell death.

type. This hypothesis was supported by recent findings that genetic variations in the TLR2, TLR4, TLR6 and TLR10 genes were associated with atopy in children [70-74].

Similar to TLRs, CD14 is a pattern recognition receptor for certain microbial molecules and expressed by APCs. Associations of different polymorphisms within the CD14 gene and cardinal features of atopic diseases, such as IgE levels [75], eczema [76], asthma severity [77] and bronchial hyperresponsiveness [78], were identified. In contrast, other studies did not replicate these associations [72, 79], possibly due to genetic variations in different study populations or differences in the kinetics of the microbial exposure [80].

\section{CO-STIMULATORY SIGNALS REGULATE ALLERGIC AIRWAY INFLAMMATION}

The development of allergen-induced airway inflammation and AHR is regulated by fine-tuning of several co-stimulatory factors. The first co-stimulatory signal for activation of naive Tcells is delivered by the interaction of CD28 with its ligands expressed on DCs, CD80 (B7.1) and CD86 (B7.2) (fig. 1) [81]. This interaction induces the expression of anti-apoptotic 


\begin{tabular}{|c|c|c|c|c|c|c|}
\hline \multirow{2}{*}{$\begin{array}{l}\text { TABLE } 2 \\
\text { Deficiency }\end{array}$} & \multicolumn{6}{|c|}{$\begin{array}{l}\text { Role of co-stimulatory molecules in the } \\
\text { development of allergen-induced immune and } \\
\text { airway responses studied in various deficient } \\
\text { germline mice }\end{array}$} \\
\hline & $\begin{array}{c}\text { BALF } \\
\text { eosinophils }\end{array}$ & AHR & $\lg E$ & $\begin{array}{c}\text { Th2 } \\
\text { cytokines }\end{array}$ & Th1 (IFN- $\gamma)$ & [Ref.] \\
\hline \multirow[t]{2}{*}{ CD28 } & $\downarrow$ & ND & $\downarrow$ & $\downarrow$ & $\leftrightarrow$ & [96] \\
\hline & $\downarrow$ & ND & $\downarrow$ & $\downarrow$ & $\downarrow$ & [97] \\
\hline CD80 & $\downarrow$ & $\downarrow$ & $\downarrow$ & $\downarrow$ & $\uparrow$ & [95] \\
\hline CD86 & $\downarrow$ & $\downarrow$ & $\downarrow$ & $\downarrow$ & $\uparrow$ & [95] \\
\hline \multirow[t]{2}{*}{ CD80/CD86 } & $\downarrow$ & $\downarrow$ & $\downarrow$ & $\downarrow$ & $\uparrow$ & [95] \\
\hline & $\downarrow$ & $\downarrow$ & $\downarrow$ & $\downarrow$ & $\uparrow$ & [98] \\
\hline \multirow[t]{3}{*}{ Icos } & ND & ND & $\downarrow$ & $\downarrow$ & $\uparrow$ & [99] \\
\hline & $\downarrow$ & ND & $\downarrow$ & $\downarrow$ & ND & [100] \\
\hline & ND & ND & $\downarrow$ & $\downarrow$ & $\uparrow$ & [101] \\
\hline \multirow[t]{2}{*}{ ICOS-L } & ND & ND & ND & $\downarrow$ & $\uparrow$ & [102] \\
\hline & $\downarrow$ & ND & $\downarrow$ & $\downarrow$ & $\uparrow$ & [103] \\
\hline \multirow[t]{2}{*}{ OX40 } & ND & ND & ND & $\downarrow$ & $\downarrow$ & [104] \\
\hline & $\downarrow$ & $\downarrow$ & $\downarrow$ & $\downarrow$ & ND & [105] \\
\hline \multirow[t]{3}{*}{ OX40L } & ND & ND & ND & $\downarrow$ & $\downarrow$ & [106] \\
\hline & $\downarrow$ & $\downarrow$ & $\downarrow$ & $\downarrow$ & $\downarrow$ & [107] \\
\hline & $\downarrow$ & $\downarrow$ & $\downarrow$ & $\downarrow$ & ND & [108] \\
\hline
\end{tabular}

BALF: bronchoalveolar lavage fluid; AHR: airway hyperresponsiveness; Ig: immunoglobulin; Th: T-helper cell; IFN: interferon; ICOS: inducible costimulatory antigen; ICOS-L: ICOS ligand; OX40: CD134; OX40L: OX40 ligand; $\downarrow$ : decreased; $\uparrow$ : increased; $\leftrightarrow$ : unchanged; ND: not determined.

molecules of the B-cell leukaemia/lymphoma gene product $(\mathrm{Bcl})$ family, permitting the clonal expansion of the activated Tcell [82] and inducing the production of cytokines IL-2, -4 and -5 . It is currently a matter of debate as to whether the differential ligation of CD28 with either CD80 or CD86, respectively, favours differentiation into Th1- or Th2-type Tcells $[83,84]$. Certainly, the cytokine milieu at the time of antigen presentation is crucial to the type of T-cell differentiation; increased production of IL-12 by DCs favours the development of Th1-mediated cellular immune responses, whereas the preferential synthesis of IL-4 and -6 by DCs that are localised at mucosal surfaces (DC2 cells) may trigger polarisation towards the Th2 phenotype $[85,86]$.

The role of CD28 in the pathogenesis of human asthma was studied using T-cells obtained from BALF and bronchial biopsy specimens from asthmatic patients [87-90]. Interestingly, the proliferation of human BALF-derived T-cells from patients with atopic asthma after in vitro stimulation with allergen was inhibited by the addition of anti-CD86, but not of anti-CD80 $\mathrm{mAb}$ [90], underscoring the critical role of CD86 in allergen-induced T-cell (Th2) responses.

The activation of T-cells through CD28 is negatively regulated by the inducible molecule cytotoxic T-lymphocyte antigen (CTLA)-4. Accordingly, inhibition of CD28 co-stimulation by means of CTLA-4-Ig suppressed the production of IL-5, -13 and -16 and RANTES (regulated on activation, normal T-cell expressed and secreted) upon allergen-specific in vitro stimulation by T-cells isolated from bronchial biopsy specimens from asthmatic subjects [88, 89]. A more detailed analysis of these experiments revealed that allergen-mediated Th2-type cytokine production in bronchial biopsy specimens was dependent upon signalling via both CD80 and CD86 [87].

In human bronchial asthma, an association between certain single nucleotide polymorphisms (SNPs) within the CTLA-4 gene and increased total serum $\operatorname{IgE}$ levels (+49A/G [91]), bronchial hyperresponsiveness (BHR) (-1147C/T and $+49 \mathrm{~A} / \mathrm{G}$ [92]) and asthma severity (-318C/T [92]) was demonstrated. In two other cohorts, no association of the $+49 \mathrm{~A} / \mathrm{G}$ and $-318 \mathrm{C} / \mathrm{T}$ polymorphisms and the development of the asthma phenotype was found $[93,94]$.

The critical role of CD28 signalling in the development of allergic airway diseases was further confirmed in mice deficient in this co-stimulatory pathway. Mice deficient in CD86 developed less airway inflammation in response to allergen sensitisation and airway challenges than their normal littermates [95]. In the same line, CD28-deficient or CD80/ CD86 double knockout mice showed virtually no signs of allergic airway inflammation (e.g. production of IgE, eosinophilic airway inflammation and development of AHR) following allergen sensitisation and airway challenges (table 2) [95, 97]. Mice deficient in CTLA-4 developed a lethal lymphoproliferative disease, which reflects the importance of this molecule in the restriction of T-cell-mediated immune responses [109].

After initial T-cell activation, effector T-cell function seems to be less dependent on the engagement of CD28 [110, 111]. Other co-stimulatory molecules, which are only expressed upon T-cell activation, take over and seem to play the dominant role in the control of the ongoing immune reaction.

A prominent member of this second line of T-cell control is inducible co-stimulatory antigen (ICOS). Initial studies on its functional properties demonstrated that co-stimulation via ICOS mainly resulted in high expression of IL-10 and -4 and minor production of other Th1 and Th2 cytokines during the initial priming and effector T-cell responses [112-114]. It was further demonstrated that the production of certain cytokines correlated with the expression density of ICOS on the cell surface [115]. Intermediate ICOS expression was associated with high production of Th2 cytokines, whereas high levels of ICOS predominantly translated into high IL-10 production. In line with these findings, it was shown that mature pulmonary DCs in the bronchial lymph nodes of mice exposed to respiratory allergen induced the development of $\mathrm{Tr}$, in a process that required T-cell co-stimulation via the ICOS-ICOS ligand (ICOS-L) pathway. The Tr produced IL-10 and showed potent inhibitory activity; when adoptively transferred into sensitised mice, Tr blocked the development of AHR. Both the development and the inhibitory function of regulatory cells were dependent upon the presence of IL-10 and on ICOS-ICOS-L interactions. These studies demonstrate that $\mathrm{Tr}$ and the ICOS-ICOS-L signalling pathway are critically involved in respiratory tolerance and downregulating pulmonary inflammation in asthma [116, 117].

Other authors have shown that adoptively transferred ICOS+ cells were capable of inducing airway inflammation upon 
subsequent allergen airway challenges, highlighting the essential role of ICOS in the development of allergic airway inflammation [115].

One study showed an association of SNPs within the ICOS gene (-693A/A and -1413A/A) with increased total IgE and allergic sensitisation to airborne allergens in a Hutterite population. Furthermore, the -1413 SNP is located at a nuclear factor- $\kappa \mathrm{B}$-binding site and peripheral blood mononuclear cells homozygous for the A allele (-1413A/A) produce significantly greater amounts of the cytokines IL-4, IL-5 and IL-13 and TNF$\alpha$. This points towards a role of ICOS in allergic diseases in humans [118].

Mice lacking ICOS or ICOS-L expression are strongly impaired in T-cell IL-4 production, resulting in impaired production of antigen-specific class-switched antibodies, such as IgG1, IgG2a, IgA and, especially, IgE (table 2) [100, 101, 103]. Interestingly, ICOS-deficient mice still develop profound IL5-mediated eosinophilic airway inflammation upon allergen sensitisation and subsequent airway challenges, indicating that ICOS may not primarily be involved in global Th2 differentiation, but is rather required for the expression of IL-4 in the effector phase [100, 119].

Another inducible co-stimulatory molecule involved in the pathogenesis of the allergic airway reaction is CD134 (OX40). This molecule is mainly expressed by activated Th2. OX40 is required for the cytoplasmic expression of the transcription factors Bcl-xL and Bcl-2, which deliver anti-apoptotic signals for pre-activated T-cells [120]. These signals are essential for the accumulation of T-cells during the primary immune response, as well as during the subsequent formation of a memory cell pool. In mice lacking OX40 signalling, strong impairment of allergic airway inflammation, with significantly reduced development of AHR, Th2 cytokine production and IgE synthesis, was observed (table 2) [105, 107].

Co-stimulation is also an effective means of downregulating Tcell functions. Signalling through the negative co-stimulatory molecule, programmed cell death (PD)-1, leads to arrest in cell cycle phase $G_{0}-G_{1}$, thus limiting an ongoing immune reaction [121]. The importance of PD-1-mediated T-cell suppression for peripheral tolerance was supported by the observation that PD-1-deficient mice developed autoimmune diseases, e.g. cardiomyopathy [122], autoimmune glomerulonephritis and arthritis [123].

In a murine model of airway inflammation, allergen sensitisation and airway challenge lead to increased expression of PD-1 ligand 1 (PD-L1) on pulmonary DCs, macrophages and B-cells isolated from lung tissues [124]. Despite this abundant expression of PD-L1, this molecule seems not to be involved in the control of allergic airway inflammation, since blockade by $\mathrm{mAb}$ did not alter the allergic phenotype [124]. In contrast, another PD-1 ligand, PD-L2, was expressed only in very low amounts by lymphocytes of unchallenged mice, with only moderate increases after allergen challenge. However, blockade of this specific ligand significantly inhibited the development of AHR, lung eosinophilia and production of Th2 cytokines [124]. This gives PD-L2 a so-far unique role in the negative regulation of allergen-induced airway responses.

\section{SUMMARY}

A complex network of enhancing and inhibitory co-stimulatory signals regulates T-cell differentiation and effector functions. Owing to their central role in allergen-mediated airway inflammation, T-cell co-stimulatory molecules constitute promising targets for novel therapeutic interventions. The state of the art regarding experimental data on the use of these signals in modulating allergen-induced T-cell responses, and the outlook for future approaches targeting co-stimulation for intervention in allergic airway diseases is discussed in more detail in the third and final part of the present series [43].

\section{REFERENCES}

1 Azzawi M, Bradley B, Jeffery PK, et al. Identification of activated $\mathrm{T}$ lymphocytes and eosinophils in bronchial biopsies in stable atopic asthma. Am Rev Respir Dis 1990; 142: 1407-1413.

2 Bradley BL, Azzawi M, Jacobson M, et al. Eosinophils, Tlymphocytes, mast cells, neutrophils, and macrophages in bronchial biopsy specimens from atopic subjects with asthma: comparison with biopsy specimens from atopic subjects without asthma and normal control subjects and relationship to bronchial hyperresponsiveness. J Allergy Clin Immunol 1991; 88: 661-674.

3 Gavett SH, Chen X, Finkelman F, Wills-Karp M. Depletion of murine CD4+ T lymphocytes prevents antigen-induced airway hyperreactivity and pulmonary eosinophilia. Am J Respir Cell Mol Biol 1994; 10: 587-593.

4 Mosmann TR, Coffman RL. TH1 and TH2 cells: different patterns of lymphokine secretion lead to different functional properties. Annu Rev Immunol 1989; 7: 145-173.

5 Robinson DS, Hamid Q, Ying S, et al. Predominant TH2like bronchoalveolar T-lymphocyte population in atopic asthma. N Engl J Med 1992; 326: 298-304.

6 Robinson D, Hamid Q, Bentley A, Ying S, Kay AB, Durham SR. Activation of CD4+ T cells, increased TH2type cytokine mRNA expression, and eosinophil recruitment in bronchoalveolar lavage after allergen inhalation challenge in patients with atopic asthma. J Allergy Clin Immunol 1993; 92: 313-324.

7 Kuperman D, Schofield B, Wills-Karp M, Grusby MJ. Signal transducer and activator of transcription factor 6 (Stat6)-deficient mice are protected from antigen-induced airway hyperresponsiveness and mucus production. $J$ Exp Med 1998; 187: 939-948.

8 Tomkinson A, Kanehiro A, Rabinovitch N, Joetham A, Cieslewicz G, Gelfand EW. The failure of STAT6deficient mice to develop airway eosinophilia and airway hyperresponsiveness is overcome by interleukin-5. Am J Respir Crit Care Med 1999; 160: 1283-1291.

9 Hamelmann E, Oshiba A, Schwarze J, et al. Allergenspecific IgE and IL-5 are essential for the development of airway hyperresponsiveness. Am J Respir Cell Mol Biol 1997; 16: 674-682.

10 Maxwell MJ, Muthu P, Pritty PE. Accidental colchicine overdose. A case report and literature review. Emerg Med J 2002; 19: 265-267.

11 Heaton T, Rowe J, Turner S, et al. An immunoepidemiological approach to asthma: identification of in-vitro T-cell 
response patterns associated with different wheezing phenotypes in children. Lancet 2005; 365: 142-149.

12 Litonjua AA, Sparrow D, Guevarra L, O'Connor GT, Weiss ST, Tollerud DJ. Serum interferon-gamma is associated with longitudinal decline in lung function among asthmatic patients: the Normative Aging Study. Ann Allergy Asthma Immunol 2003; 90: 422-428.

13 Koh YI, Choi IS, Lee HC. Relationship between changes in interferon- $\gamma$ production by peripheral blood $\mathrm{T}$ cells and changes in peak expiratory flow rate in patients with chronic stable asthma. Clin Exp Allergy 2002; 32: 1734-1738.

14 Krug N, Madden J, Redington AE, et al. T-cell cytokine profile evaluated at the single cell level in BAL and blood in allergic asthma. Am J Respir Cell Mol Biol 1996; 14: 319-326.

15 Smart JM, Kemp AS. Increased Th1 and Th2 allergeninduced cytokine responses in children with atopic disease. Clin Exp Allergy 2002; 32: 796-802.

16 Krug N, Erpenbeck VJ, Balke K, et al. Cytokine profile of bronchoalveolar lavage-derived $\mathrm{CD}^{+}, \mathrm{CD}^{+}$, and $\gamma \delta \mathrm{T}$ cells in people with asthma after segmental allergen challenge. Am J Respir Cell Mol Biol 2001; 25: 125-131.

17 Coyle AJ, Le Gros G, Bertrand C, et al. Interleukin-4 is required for the induction of lung Th2 mucosal immunity. Am J Respir Cell Mol Biol 1995; 13: 54-59.

18 Corry DB, Folkesson HG, Warnock ML, et al. Interleukin 4 , but not interleukin 5 or eosinophils, is required in a murine model of acute airway hyperreactivity. J Exp Med 1996; 183: 109-117.

19 Brusselle GG, Kips JC, Tavernier JH, et al. Attenuation of allergic airway inflammation in IL-4 deficient mice. Clin Exp Allergy 1994; 24: 73-80.

20 Hamelmann E, Takeda K, Haczku A, et al. Interleukin (IL)-5 but not immunoglobulin $\mathrm{E}$ reconstitutes airway inflammation and airway hyperresponsiveness in IL-4deficient mice. Am J Respir Cell Mol Biol 2000; 23: 327-334.

21 Hamelmann E, Oshiba A, Loader J, et al. Antiinterleukin5 antibody prevents airway hyperresponsiveness in a murine model of airway sensitization. Am J Respir Crit Care Med 1997; 155: 819-825.

22 Hamelmann E, Takeda K, Schwarze J, Vella AT, Irvin CG, Gelfand EW. Development of eosinophilic airway inflammation and airway hyperresponsiveness requires interleukin-5 but not immunoglobulin E or B lymphocytes. Am J Respir Cell Mol Biol 1999; 21: 480-489.

23 Lee JJ, McGarry MP, Farmer SC, et al. Interleukin-5 expression in the lung epithelium of transgenic mice leads to pulmonary changes pathognomonic of asthma. $J$ Exp Med 1997; 185: 2143-2156.

24 Lee NA, McGarry MP, Larson KA, Horton MA, Kristensen $A B$, Lee JJ. Expression of IL-5 in thymocytes/T cells leads to the development of a massive eosinophilia, extramedullary eosinophilopoiesis, and unique histopathologies. J Immunol 1997; 158: 1332-1344.

25 Lefort J, Bachelet CM, Leduc D, Vargaftig BB. Effect of antigen provocation of IL-5 transgenic mice on eosinophil mobilization and bronchial hyperresponsiveness. J Allergy Clin Immunol 1996; 97: 788-799.

26 Hogan SP, Koskinen A, Matthaei KI, Young IG, Foster PS. Interleukin-5-producing CD4+ $\mathrm{T}$ cells play a pivotal role in aeroallergen-induced eosinophilia, bronchial hyperreactivity, and lung damage in mice. Am J Respir Crit Care Med 1998; 157: 210-218.

27 Foster PS, Hogan SP, Ramsay AJ, Matthaei KI, Young IG. Interleukin 5 deficiency abolishes eosinophilia, airways hyperreactivity, and lung damage in a mouse asthma model. J Exp Med 1996; 183: 195-201.

28 Kung TT, Luo B, Crawley Y, et al. Effect of anti-mIL-9 antibody on the development of pulmonary inflammation and airway hyperresponsiveness in allergic mice. Am J Respir Cell Mol Biol 2001; 25: 600-605.

29 McLane MP, Haczku A, van de Rijn M, et al. Interleukin-9 promotes allergen-induced eosinophilic inflammation and airway hyperresponsiveness in transgenic mice. Am J Respir Cell Mol Biol 1998; 19: 713-720.

30 Temann UA, Geba GP, Rankin JA, Flavell RA. Expression of interleukin 9 in the lungs of transgenic mice causes airway inflammation, mast cell hyperplasia, and bronchial hyperresponsiveness. J Exp Med 1998; 188: 1307-1320.

31 Townsend JM, Fallon GP, Matthews JD, Smith P, Jolin EH, McKenzie NA. IL-9-deficient mice establish fundamental roles for IL-9 in pulmonary mastocytosis and goblet cell hyperplasia but not T cell development. Immunity 2000; 13: 573-583.

32 Wills-Karp M, Luyimbazi J, Xu X, et al. Interleukin-13: central mediator of allergic asthma. Science 1998; 282: 2258-2261.

33 Grunig G, Warnock M, Wakil AE, et al. Requirement for IL-13 independently of IL-4 in experimental asthma. Science 1998; 282: 2261-2263.

34 Taube C, Duez C, Cui ZH, et al. The role of IL-13 in established allergic airway disease. J Immunol 2002; 169: 6482-6489.

35 Zhu Z, Homer RJ, Wang Z, et al. Pulmonary expression of interleukin-13 causes inflammation, mucus hypersecretion, subepithelial fibrosis, physiologic abnormalities, and eotaxin production. J Clin Invest 1999; 103: 779-788.

36 Walter DM, McIntire JJ, Berry G, et al. Critical role for IL13 in the development of allergen-induced airway hyperreactivity. J Immunol 2001; 167: 4668-4675.

37 Leckie MJ, ten Brinke A, Khan J, et al. Effects of an interleukin-5 blocking monoclonal antibody on eosinophils, airway hyper-responsiveness, and the late asthmatic response. Lancet 2000; 356: 2144-2148.

38 Flood-Page PT, Menzies-Gow AN, Kay AB, Robinson DS. Eosinophil's role remains uncertain as anti-interleukin-5 only partially depletes numbers in asthmatic airway. Am J Respir Crit Care Med 2003; 167: 199-204.

39 Kips JC, O'Connor BJ, Langley SJ, et al. Effect of SCH55700, a humanized anti-human interleukin-5 antibody, in severe persistent asthma: a pilot study. Am J Respir Crit Care Med 2003; 167: 1655-1659.

40 Borish LC, Nelson HS, Corren J, et al. Efficacy of soluble IL-4 receptor for the treatment of adults with asthma. J Allergy Clin Immunol 2001; 107: 963-970.

41 Borish LC, Nelson HS, Lanz MJ, et al. Interleukin-4 receptor in moderate atopic asthma. A phase I/II randomized, placebo-controlled trial. Am J Respir Crit Care Med 1999; 160: 1816-1823.

42 Boushey HA, Fahy JV. Targeting cytokines in asthma therapy: round one. Lancet 2000; 356: 2114-2116. 
43 Beier KC, Kallinich T, Hamelmann E. Novel targets for the treatment of allergic airway disease. Eur Respir J 2007 (in press).

44 Berry MA, Hargadon B, Shelley M, et al. Evidence of a role of tumor necrosis factor $\alpha$ in refractory asthma. $N$ Engl J Med 2006; 354: 697-708.

45 Corrigan CJ, Shiner RJ, Shakur BH, Ind PW. Methotrexate therapy of oral corticosteroid-dependent asthmatics reduces serum immunoglobulins: correlation with clinical response to therapy. Clin Exp Allergy 2005; 35: 579-584.

46 Bach JF. The effect of infections on susceptibility to autoimmune and allergic diseases. N Engl J Med 2002; 347: 911-920.

47 Stock P, DeKruyff RH, Umetsu DT. Inhibition of the allergic response by regulatory T cells. Curr Opin Allergy Clin Immunol 2006; 6: 12-16.

48 Hori S, Nomura T, Sakaguchi S. Control of regulatory T cell development by the transcription factor Foxp3. Science 2003; 299: 1057-1061.

49 Fontenot JD, Rudensky AY. A well adapted regulatory contrivance: regulatory $\mathrm{T}$ cell development and the forkhead family transcription factor Foxp3. Nat Immunol 2005; 6: 331-337.

50 Sakaguchi S. Naturally arising Foxp3-expressing $\mathrm{CD} 25+\mathrm{CD} 4+$ regulatory $\mathrm{T}$ cells in immunological tolerance to self and non-self. Nat Immunol 2005; 6: 345-352.

51 Fontenot JD, Rasmussen JP, Williams LM, Dooley JL, Farr AG, Rudensky AY. Regulatory $T$ cell lineage specification by the forkhead transcription factor foxp3. Immunity 2005; 22: 329-341.

52 Bennett CL, Christie J, Ramsdell F, et al. The immune dysregulation, polyendocrinopathy, enteropathy, Xlinked syndrome (IPEX) is caused by mutations of FOXP3. Nat Genet 2001; 27: 20-21.

53 Wildin RS, Ramsdell F, Peake J, et al. X-linked neonatal diabetes mellitus, enteropathy and endocrinopathy syndrome is the human equivalent of mouse scurfy. Nat Genet 2001; 27: 18-20.

54 Chatila TA, Blaeser F, Ho N, et al. JM2, encoding a fork head-related protein, is mutated in X-linked autoimmunity-allergic disregulation syndrome. J Clin Invest 2000; 106: R75-R81.

55 Fontenot JD, Gavin MA, Rudensky AY. Foxp3 programs the development and function of CD4+CD25+ regulatory T cells. Nat Immunol 2003; 4: 330-336.

56 Hadeiba H, Locksley RM. Lung CD25 CD4 regulatory T cells suppress type 2 immune responses but not bronchial hyperreactivity. J Immunol 2003; 170: 5502-5510.

57 Stassen M, Jonuleit H, Muller C, et al. Differential regulatory capacity of $\mathrm{CD} 25+\mathrm{T}$ regulatory cells and preactivated CD25+ $\mathrm{T}$ regulatory cells on development, functional activation, and proliferation of Th2 cells. J Immunol 2004; 173: 267-274.

58 Karlsson MR, Rugtveit J, Brandtzaeg P. Allergen-responsive CD4+CD25+ regulatory $T$ cells in children who have outgrown cow's milk allergy. J Exp Med 2004; 199: 1679-1688.

59 Ling EM, Smith T, Nguyen XD, et al. Relation of CD4+CD25+ regulatory T-cell suppression of allergendriven T-cell activation to atopic status and expression of allergic disease. Lancet 2004; 363: 608-615.
60 Grindebacke H, Wing K, Andersson AC, Suri-Payer E, Rak S, Rudin A. Defective suppression of Th2 cytokines by CD4CD25 regulatory $\mathrm{T}$ cells in birch allergics during birch pollen season. Clin Exp Allergy 2004; 34: 1364-1372.

61 Lin CH, Hunig T. Efficient expansion of regulatory T cells in vitro and in vivo with a CD28 superagonist. Eur J Immunol 2003; 33: 626-638.

62 Suntharalingam G, Perry MR, Ward S, et al. Cytokine storm in a phase 1 trial of the anti-CD28 monoclonal antibody TGN1412. N Engl J Med 2006; 355: 1018-1028.

63 Watanabe T, Masuyama J, Sohma Y, et al. CD52 is a novel costimulatory molecule for induction of CD4+ regulatory T cells. Clin Immunol 2006; 120: 247-259.

64 Beier KC, Kallinich T, Hamelmann E. Master switches of T-cell activation and differentiation. Eur Respir J 2007; 29: 804-812.

65 Geissmann F, Jung S, Littman DR. Blood monocytes consist of two principal subsets with distinct migratory properties. Immunity 2003; 19: 71-82.

66 Vermaelen KY, Carro-Muino I, Lambrecht BN, Pauwels RA. Specific migratory dendritic cells rapidly transport antigen from the airways to the thoracic lymph nodes. J Exp Med 2001; 193: 51-60.

67 Eisenbarth SC, Piggott DA, Huleatt JW, Visintin I, Herrick CA, Bottomly K. Lipopolysaccharide-enhanced, Toll-like receptor 4-dependent $\mathrm{T}$ helper cell type 2 responses to inhaled antigen. J Exp Med 2002; 196: 1645-1651.

68 Reinhardt RL, Bullard DC, Weaver CT, Jenkins MK. Preferential accumulation of antigen-specific effector CD4 T cells at an antigen injection site involves CD62Edependent migration but not local proliferation. J Exp Med 2003; 197: 751-762.

69 Manetti R, Parronchi P, Giudizi MG, et al. Natural killer cell stimulatory factor (interleukin 12 [IL-12]) induces $\mathrm{T}$ helper type 1 (Th1)-specific immune responses and inhibits the development of IL-4-producing Th cells. J Exp Med 1993; 177: 1199-1204.

70 Eder W, Klimecki W, Yu L, et al. Toll-like receptor 2 as a major gene for asthma in children of European farmers. $J$ Allergy Clin Immunol 2004; 113: 482-488.

71 Yang IA, Barton SJ, Rorke S, et al. Toll-like receptor 4 polymorphism and severity of atopy in asthmatics. Genes Immun 2004; 5: 41-45.

72 Fageras BM, Hmani-Aifa M, Lindstrom A, et al. A TLR4 polymorphism is associated with asthma and reduced lipopolysaccharide-induced interleukin-12 (p70) responses in Swedish children. J Allergy Clin Immunol 2004; 114: 561-567.

73 Tantisira K, Klimecki WT, Lazarus R, et al. Toll-like receptor 6 gene (TLR6): single-nucleotide polymorphism frequencies and preliminary association with the diagnosis of asthma. Genes Immun 2004; 5: 343-346.

74 Lazarus R, Raby BA, Lange C, et al. TOLL-like receptor 10 genetic variation is associated with asthma in two independent samples. Am J Respir Crit Care Med 2004; 170: 594-600.

75 Baldini M, Lohman IC, Halonen M, Erickson RP, Holt PG, Martinez FD. A polymorphism in the 5 ' flanking region of the CD14 gene is associated with circulating soluble 
CD14 levels and with total serum immunoglobulin E. Am J Respir Cell Mol Biol 1999; 20: 976-983.

76 Litonjua AA, Belanger K, Celedon JC, et al. Polymorphisms in the $5^{\prime}$ region of the CD14 gene are associated with eczema in young children. J Allergy Clin Immunol 2005; 115: 1056-1062.

77 Zambelli-Weiner A, Ehrlich E, Stockton ML, et al. Evaluation of the CD14/-260 polymorphism and house dust endotoxin exposure in the Barbados Asthma Genetics Study. J Allergy Clin Immunol 2005; 115: 1203-1209.

78 O'Donnell AR, Toelle BG, Marks GB, et al. Age-specific relationship between CD14 and atopy in a cohort assessed from age 8 to 25 years. Am J Respir Crit Care Med 2004; 169: 615-622.

79 Kedda MA, Lose F, Duffy D, Bell E, Thompson PJ, Upham J. The CD14 C-159T polymorphism is not associated with asthma or asthma severity in an Australian adult population. Thorax 2005; 60: 211-214.

80 Eder W, Klimecki W, Yu L, et al. Opposite effects of CD 14/-260 on serum IgE levels in children raised in different environments. J Allergy Clin Immunol 2005; 116: 601-607.

81 Vermaelen K, Pauwels R. Accelerated airway dendritic cell maturation, trafficking, and elimination in a mouse model of asthma. Am J Respir Cell Mol Biol 2003; 29: 405409.

82 Harding FA, McArthur JG, Gross JA, Raulet DH, Allison JP. CD28-mediated signalling co-stimulates murine $\mathrm{T}$ cells and prevents induction of anergy in T-cell clones. Nature 1992; 356: 607-609.

83 Natesan M, Razi-Wolf Z, Reiser H. Costimulation of IL-4 production by murine B7-1 and B7-2 molecules. J Immunol 1996; 156: 2783-2791.

84 Kuchroo VK, Das MP, Brown JA, et al. B7-1 and B7-2 costimulatory molecules activate differentially the Th1/ Th2 developmental pathways: application to autoimmune disease therapy. Cell 1995; 80: 707-718.

85 Stumbles PA, Thomas JA, Pimm CL, et al. Resting respiratory tract dendritic cells preferentially stimulate $\mathrm{T}$ helper cell type 2 (Th2) responses and require obligatory cytokine signals for induction of Th1 immunity. J Exp Med 1998; 188: 2019-2031.

86 Constant SL, Brogdon JL, Piggott DA, et al. Resident lung antigen-presenting cells have the capacity to promote Th2 T cell differentiation in situ. J Clin Invest 2002; 110: 1441-1448.

87 Jaffar ZH, Stanciu L, Pandit A, Lordan J, Holgate ST, Roberts K. Essential role for both CD80 and CD86 costimulation, but not CD40 interactions, in allergeninduced Th2 cytokine production from asthmatic bronchial tissue: role for $\alpha \beta$, but not $\gamma \delta$, T cells. J Immunol 1999; 163: 6283-6291.

88 Jaffar Z, Roberts K, Pandit A, Linsley P, Djukanovic R, Holgate S. B7 costimulation is required for IL-5 and IL-13 secretion by bronchial biopsy tissue of atopic asthmatic subjects in response to allergen stimulation. Am J Respir Cell Mol Biol 1999; 20: 153-162.

89 Hidi R, Riches V, Al Ali M, et al. Role of B7-CD28/CTLA4 costimulation and NF- $\mathrm{KB}$ in allergen-induced $\mathrm{T}$ cell chemotaxis by IL-16 and RANTES. J Immunol 2000; 164: 412-418.
90 Larche M, Till SJ, Haselden BM, et al. Costimulation through CD86 is involved in airway antigen-presenting cell and $\mathrm{T}$ cell responses to allergen in atopic asthmatics. $J$ Immunol 1998; 161: 6375-6382.

91 Howard TD, Postma DS, Hawkins GA, et al. Fine mapping of an IgE-controlling gene on chromosome 2q: analysis of CTLA4 and CD28. J Allergy Clin Immunol 2002; 110: 743-751.

92 Lee SY, Lee YH, Shin C, et al. Association of asthma severity and bronchial hyperresponsiveness with a polymorphism in the cytotoxic T-lymphocyte antigen-4 gene. Chest 2002; 122: 171-176.

93 Nakao F, Ihara K, Ahmed S, et al. Lack of association between CD28/CTLA-4 gene polymorphisms and atopic asthma in the Japanese population. Exp Clin Immunogenet 2000; 17: 179-184.

94 Heinzmann A, Plesnar C, Kuehr J, Forster J, Deichmann KA. Common polymorphisms in the CTLA4 and CD28 genes at 2q33 are not associated with asthma or atopy. Eur J Immunogenet 2000; 27: 57-61.

95 Mark DA, Donovan CE, De Sanctis GT, et al. B7-1 (CD80) and B7-2 (CD86) have complementary roles in mediating allergic pulmonary inflammation and airway hyperresponsiveness. Am J Respir Cell Mol Biol 2000; 22: 265-271.

96 Mathur M, Herrmann K, Qin Y, et al. CD28 interactions with either CD80 or CD86 are sufficient to induce allergic airway inflammation in mice. Am J Respir Cell Mol Biol 1999; 21: 498-509.

97 Burr JS, Kimzey SL, Randolph DR, Green JM. CD28 and CTLA4 coordinately regulate airway inflammatory cell recruitment and T-helper cell differentiation after inhaled allergen. Am J Respir Cell Mol Biol 2001; 24: 563-568.

98 Deurloo DT, van Berkel MA, van Esch BC, et al. CD28/ CTLA4 double deficient mice demonstrate crucial role for B7 co-stimulation in the induction of allergic lower airways disease. Clin Exp Allergy 2003; 33: 1297-1304.

99 McAdam AJ, Greenwald RJ, Levin MA, et al. ICOS is critical for CD40-mediated antibody class switching. Nature 2001; 409: 102-105.

100 Dong C, Juedes AE, Temann UA, et al. ICOS costimulatory receptor is essential for T-cell activation and function. Nature 2001; 409: 97-101.

101 Tafuri A, Shahinian A, Bladt F, et al. ICOS is essential for effective T-helper-cell responses. Nature 2001; 409: 105-109.

102 Wong SC, Oh E, $\mathrm{Ng} \mathrm{CH}$, Lam KP. Impaired germinal center formation and recall $\mathrm{T}$-cell-dependent immune responses in mice lacking the costimulatory ligand B7H2. Blood 2003; 102: 1381-1388.

103 Mak TW, Shahinian A, Yoshinaga SK, et al. Costimulation through the inducible costimulator ligand is essential for both $\mathrm{T}$ helper and $\mathrm{B}$ cell functions in $\mathrm{T}$ cell-dependent $\mathrm{B}$ cell responses. Nat Immunol 2003; 4: 765-772.

104 Gramaglia I, Jember A, Pippig SD, Weinberg AD, Killeen N, Croft M. The OX40 costimulatory receptor determines the development of CD4 memory by regulating primary clonal expansion. J Immunol 2000; 165: 3043-3050.

105 Jember AG, Zuberi R, Liu FT, Croft M. Development of allergic inflammation in a murine model of asthma is dependent on the costimulatory receptor OX40. J Exp Med 2001; 193: 387-392. 
106 Chen AI, McAdam AJ, Buhlmann JE, et al. Ox40-ligand has a critical costimulatory role in dendritic cell:T cell interactions. Immunity 1999; 11: 689-698.

107 Arestides RS, He H, Westlake RM, et al. Costimulatory molecule OX40L is critical for both Th1 and Th2 responses in allergic inflammation. Eur J Immunol 2002; 32: $2874-2880$.

108 Hoshino A, Tanaka Y, Akiba H, et al. Critical role for OX40 ligand in the development of pathogenic Th2 cells in a murine model of asthma. Eur J Immunol 2003; 33: 861-869.

109 Tivol EA, Borriello F, Schweitzer AN, Lynch WP, Bluestone JA, Sharpe AH. Loss of CTLA-4 leads to massive lymphoproliferation and fatal multiorgan tissue destruction, revealing a critical negative regulatory role of CTLA-4. Immunity 1995; 3: 541-547.

110 London CA, Lodge MP, Abbas AK. Functional responses and costimulator dependence of memory CD4+ T cells. J Immunol 2000; 164: 265-272.

111 Gause WC, Mitro V, Via C, Linsley P, Urban JF Jr, Greenwald RJ. Do effector and memory $\mathrm{T}$ helper cells also need B7 ligand costimulatory signals? J Immunol 1997; 159: 1055-1058.

112 Hutloff A, Dittrich AM, Beier KC, et al. ICOS is an inducible T-cell co-stimulator structurally and functionally related to CD28. Nature 1999; 397: 263-266.

113 McAdam AJ, Chang TT, Lumelsky AE, et al. Mouse inducible costimulatory molecule (ICOS) expression is enhanced by CD28 costimulation and regulates differentiation of CD4+ T cells. J Immunol 2000; 165: 5035-5040.

114 Beier KC, Hutloff A, Dittrich AM, et al. Induction, binding specificity and function of human ICOS. Eur J Immunol 2000; 30: 3707-3717.

115 Lohning M, Hutloff A, Kallinich T, et al. Expression of ICOS in vivo defines CD4+ effector $\mathrm{T}$ cells with high inflammatory potential and a strong bias for secretion of interleukin 10. J Exp Med 2003; 197: 181-193.

116 Akbari O, Freeman GJ, Meyer EH, et al. Antigen-specific regulatory $\mathrm{T}$ cells develop via the ICOS-ICOS-ligand pathway and inhibit allergen-induced airway hyperreactivity. Nat Med 2002; 8: 1024-1032.

117 Stock P, Akbari O, Berry G, Freeman GJ, DeKruyff RH, Umetsu DT. Induction of T helper type 1-like regulatory cells that express Foxp3 and protect against airway hyper-reactivity. Nat Immunol 2004; 5: 1149-1156.

118 Shilling RA, Pinto JM, Decker DC, et al. Cutting edge: polymorphisms in the ICOS promoter region are associated with allergic sensitization and Th2 cytokine production. J Immunol 2005; 175: 2061-2065.

119 Tesciuba AG, Subudhi S, Rother RP, et al. Inducible costimulator regulates Th2-mediated inflammation, but not Th2 differentiation, in a model of allergic airway disease. J Immunol 2001; 167: 1996-2003.

120 Stuber E, Neurath M, Calderhead D, Fell HP, Strober W. Cross-linking of OX40 ligand, a member of the TNF/NGF cytokine family, induces proliferation and differentiation in murine splenic B cells. Immunity 1995; 2: 507-521.

121 Agata Y, Kawasaki A, Nishimura H, et al. Expression of the PD-1 antigen on the surface of stimulated mouse T and B lymphocytes. Int Immunol 1996; 8: 765-772.

122 Nishimura H, Okazaki T, Tanaka Y, et al. Autoimmune dilated cardiomyopathy in PD-1 receptor-deficient mice. Science 2001; 291: 319-322.

123 Nishimura $H$, Nose $M$, Hiai $H$, Minato $N$, Honjo $T$. Development of lupus-like autoimmune diseases by disruption of the PD-1 gene encoding an ITIM motifcarrying immunoreceptor. Immunity 1999; 11: 141-151.

124 Matsumoto K, Inoue H, Nakano T, et al. B7-DC regulates asthmatic response by an IFN- $\gamma$-dependent mechanism. $J$ Immunol 2004; 172: 2530-2541. 